\title{
What DoEs Not Kill You MAKES You STRONGER. LEGAL EVOLUTIONISM AND THE UNUSUAL CASE OF GOOGLE NEWS
}

\section{Massimiliano Granieri ${ }^{1,2}$}

Keywords: Google News, Copyright, Snippets, Neighboring rights, Legal change

\begin{abstract}
Google News is an unusual case where the dominant firm of the market for searches allegedly abuses its position by using news which publishers consider as subject to their copyright. Publishers claim that there is an antitrust violation and Google's service diverts users on its sites, reducing traffic for competitors. All such allegations hinge on the issue of snippets as really works of authorship, as such protected. Several interpretations of copyright laws are possible to provide an answer. Some states have responded by enacting new legislation and introducing neighboring rights on fragments of news, thus preventing Google from freely using headlines and excerpts for it purposes. Where protection was reinforced, Google's reaction was to discontinue the service, while in other situations it entered into private arrangements with online publishers, thus confirming that in an evolutionary perspective copyright laws only set the stage for efficient solutions that are found by market players in the shadow of the law.
\end{abstract}

\footnotetext{
${ }^{1}$ Department of Mechanical and Industrial Engineering, University of Brescia Health \& Wealth.

2 Article based on the speech given at the conference: "Diritti e benessere del consumatore nell'ecosistema digitale", Rome, 14 May 2015.
}

\section{An Evolutionary Perspective About Google News}

The Google News case offers an enticing perspective for scholars interested in investigating the reasons that explain legal change. The case adds to the history of copyright and to the relationship between technological progress and regulatory responses, concurring to a possible reconstruction of how legal systems adapted over time ${ }^{3}$. This short papers supports the view that evolutionism applied to law provides a convincing paradigm to describe (and possibly predict) the interaction of intellectual property protection, spontaneous private ordering and state intervention.

Apparently, the topic only bears a feeble link to consumers' welfare but as a matter of fact Google News is mostly about the benefits that consumers receive by access to information and to the effects related to the prohibition for Google to offer such service. Any regulatory solution about content aggregation should

\footnotetext{
${ }^{3}$ One of the most rich and problematic reconstructions of this history (from an economic and technological perspective) is still A. JOHNS, The Intellectual Property Wars from Gutenberg to Gates, The University of Chicago Press, 2009.
} 
always consider consumer welfare as one of the values in need for consideration within the process.

\section{A New Case at the Interface of INTEllectual Property and ANTITRUST}

The Google News controversy features undoubtedly innovative traits. Google is today a pervasive company that uses its platform for free searches as an enabling factor of competitiveness, by offering a growing number of services. Some of those are free, some others are paid for, others follow the "freemium" model ${ }^{4}$. Attractiveness of Google as a business partner for companies largely depends on its installed base of users that benefit from free access to its search engine and to organic results. The initial value proposition was probably based on relevance of the results provided (that explains how Google ousted other search engines); eventually, what made (and still makes) Google's platform desirable is also the large proportion of internet users benefitting from Google's services.

The main driver of revenues was originally, and still is, advertising from undertakings willing to gain visibility over the internet. The pages

4 An interesting discussion about (and a reframing of) the meaning of "free" in digital market is now offered by M.S. GAL, D.L. Rubinfeld, The Hidden Costs of Free Goods: Implications for Antitrust Enforcement, available at www.ssrn.com organized by Google with relevant results serve this purpose, while providing users with the structured information they need. Of course, over time the offer of services, the business model and the revenues model changed and became more sophisticate. As to search results, Google is now moving away from the "tenblue link" model and is focusing on the direct supply of content ${ }^{5}$. Revenues from advertising are also based on a sharing model and other services (for instance, integration with Google Maps and geo-localization of commercial activities) are complementing the initial proposition.

Google News is part of the described strategy: the more users are attracted to Google's sites, the higher the value for Google's paying customers, such as company advertising their products. Although some scholars have argued this is not the case of a two-sided market, yet the model fits abundantly the way Google works ${ }^{6}$.

\footnotetext{
5 This change in the business model is highlighted by Google itself in its defense against the decision of the European Commission to initiate an antitrust action against certain practices of Google in providing results on its search engine. See the post on http://googlepolicyeurope.blogspot.be/2015/08/impro ving-quality-isnt-anti-competitive.html (last visit, August $28,2015)$.

6 G. LuCCHETTA, Is the Google Platfrom a Two-Sided Market?, 10 Journal of Competition Law \& Economics 185 (2013), expressed the view that Google does not operate on a two-sided market. Also doubtful A. MACCHIATI, $I$ motori di ricerca su Internet $e$ il mercato delle news. Profili antitrust e regolamentari, in Mercato Concorrenza Regole, 2010, 477. Contra, and more convincingly, V. VISCO COMANDINI, Google e $i$ mercati dei servizi di ricerca su Internet, in Mercato Concorrenza Regole, 2013, 547.
} 
Google News is a service that Mountain View provides for free. Google arranges snippets that is, fragments of news, with headlines, thumbnails and pictures - that give the user a quick view at a glance of relevant news ${ }^{7}$. The reason for providing this service for free is in line with the dynamics of a two-sided market: attracting users on Google's sites as a precondition for charging advertising services on the paying side of the market ${ }^{8}$.

These services cause Google remarkable problems with publishing companies (as it was with Google Books) and with online newspapers, that claim infringement of their intellectual property rights on the news. The assumption, of course, is that news are subject to copyright and that Google is in infringement. But the assumption might be incorrect considering that Google uses the information conveyed by the news to create a snippet and it is still unclear whether a snippet is technically a copy under copyright laws.

Newspapers complain about Google for the symmetric reason Google provides the service: using snippets allegedly diverts online traffic from their websites to Google's, thus reducing their expectations of revenues from

\footnotetext{
7 The same practice is used by Google for books; for its consequences, see R. PARDOLESI, I. LINCESSO, "Glourious Basterds»: meraviglie e sortilegi del Google Books Settlement, in Foro it., 2011, V, 11.

${ }^{8}$ B. Edelman, Does Google Leverage Market Power Through Tying and Bundling?, 11 Journal of Competition Law \& Economics 1, 15 (2015), advances the hypothesis that this is a de facto tying practice by Google, which is trying to extend its alleged dominance on the market for searches to other markets.
}

advertising $^{9}$. In this respect, they claim Google becomes a direct (unfair) competitor in the market for news, while not bearing costs associated with collecting, screening and publishing information ${ }^{10}$. Moreover, since Google is a dominant firm on the market (which one is still part of the discussion), infringement of copyright is part of a larger strategy to abuse competitors and force them out of the competitive arena. Here is when competition law is called into question and antitrust authorities start their investigations. The goal of competitors invoking antitrust rules is clear: if Google does not stop free riding on news, then it has to pay for the use.

Whether there is a cause of action in copyright is something that needs few more words. As to the antitrust claim - that is based on the assertion of copyright infringement - it shows unexpected traits. The most debated antitrust cases concerning intellectual property rights were about right owners using their rights to exclude competitors: IBM, Xerox, Microsoft, Kodak, Magill, IMS. Here the perspective is

\footnotetext{
${ }^{9}$ Newspapers also complain about the editorial policy of Google that is supposed to be not entirely clear. E. GOLDMAN, Revisiting Search Engine Bias, 38 William and Mitchell Law Review 96, 108 (2011), has stressed that, with respect to editorial policy, traditional newspapers have not been champions either.

10 Rupert Murdoch (not by chance) has written that "Google is a "platform for piracy and the spread of malicious networks" and "a company that boasts about its ability to track traffic [but] chooses to ignore the unlawful and unsavoury content that surfaces after the simplest of searches». Google's answer is available in the post http://googlepolicyeurope.blogspot.co.uk/2014/09/dea r-rupert_25.html (last visit, September 27, 2015).
} 
completely new: the right owners are the alleged victims of abuse, by a company that apparently does not care much about copyright. In other words, the case is about a copyright infringement that turns into an abuse of dominant position because the infringer has market power. And the effect is to trigger the antitrust remedies that, seen from the defendant, are much more worrisome and effective.

\section{News as Copyright Subject MATTER}

If there is an antitrust claim and if the conduct of Google amounts to copyright infringement depends on an antecedent, that is to say the fact "news" - as such or in the form of snippets as they appear on Google News - are protected by copyright. The answer cannot be stated in abstract terms, but is a question of national law. Moreover, to the extent it is a genuine issue of copyright, it does not involve Google exclusively, but also expands to content aggregation as a business model in digital markets. As a consequence, any interpretation of copyright laws aimed at Google News eventually will have an impact on other firms, of different sizes, that make their living by collecting and aggregating data, thus generating more value for users. Incidentally (but this is an issue that goes far beyond the aim of this paper), there are related aspects of fundamental rights, including freedom of speech and rights of information (both to inform and to be informed) that can be strongly influenced by copyright interpretations concerning digital content.

In very general terms, the issue of copyright protection on snippets can be dealt with under two opposite perspectives: (i) yes, snippets are subject to copyright, either as such or as derivative works; (ii) no, snippets are unprotected as they make use of the news as a disembodied piece of information that remains in public domain. The first perspective would project a property right on Google and on all other content aggregators; a service like Google News would still be possible in principle, under the condition that Google pays for the use of the news and that online newspapers agree. For Google News to remain a free service this interpretation bears negative consequences and it is indeed disfavored by Google.

The second perspective departs from the proprietary paradigm and, intuitively, is disfavored by newspapers and publishers, not as much as for the undisturbed use of the news, but for the fact that, in a two-sided market setting, Google News generates traffic and attention for Google's services that, so it goes the story by news publishers, attract advertising. As a consequence, Google's increased competitiveness and profitability comes at the expenses of publishers' investments in selecting reliable news. Google opposes this view, suggesting that its goal is not to make users stay on the snippets, but rather to rebound onto the news' original source, because its business is about providing users with directions on where to go. Under this perspective, Google improves the visibility of the news and generates traffic for publishers, 
while increasing the speed news circulate to the benefits of internet users.

There is a third possible interpretation about the relationship between Google News and copyright protection. It can be assumed that snippets are subject to intellectual property, but their use falls under one of the exceptions or limitations to copyright (or, as far as common law countries are concerned, under the fair uses doctrine $^{11}$ ). In Europe, this possible space of freedom depends on national legislation and Directive 29/2001/EC on the harmonization of certain aspects of copyright and related rights in the information society also provides room for a harmonized solution across member states. This third possible solution is risky for a number of reasons. First, it gives discretionary power to member states that might be captured by the industry and come up with idiosyncratic (and possibly diverse) solutions that would further fragment the internal market for intellectual property rights. Second, it reinforces indirectly the existence of a copyright protection on snippets. Third, it is eventually left to courts in its actual application and judges so far have often indulged in

1117 U.S.C. $\int 107$ (Limitations on exclusive rights: Fair use). For a comment applied to Google R.F. REYNOLDS, Google News and Public Policy's Influence on Fair Use in Online Infringement Controversies, $25 \mathrm{~J}$. Civ. Rts. \& Econ. Dev. 973 (2011). Associated Press v. Meltwater U.S. Holdings, Inc., 931 F. Supp. 2d 537, 537 (S.D.N.Y. 2013), has stated that news aggregation is not shielded by the fair use doctrine. For a (only partially) negative comment on the decision see D.J. QuINN, Associated Press v. Meltwater: Are Courts being Fair to News Aggregator?, 15 Minn. J.L. Sci. \& Tech. 1189 (2014). restrictive interpretations of fair uses. On the other hand, an exception to copyright is also a way towards a liability rule, that might (at least under certain conditions) lead to superior results than just the digital alternatives of property rights as opposed to public domain.

Dissatisfied with any of the solutions above, some states in Europe, lobbied by the online newspapers and publishing companies, have pursued the option of neighboring rights, which is fundamentally about adopting the property right perspective. Also this option demands a discussion.

\section{NEIGHBORING RigHTS ON SNIPPETS}

Spain was one of the first states to cut short the debate and to introduce a solution of neighboring rights ${ }^{12}$. And it did it by adopting a perspective of inalienability of rights ("irrenunciable") on the news and on the duty for anyone willing to use it to pay a "compensación equitativa". Unauthorized use can be punished with fines up to 600.000 euros.

The direct consequence of such stern solution was Google discontinuing the Google News services in Spain. Here we have a first element that reconnects Google News with consumers'

\footnotetext{
12 Ley 21/2014, de 4 de noviembre, por la que se modifica el texto refundido de la Ley de Propiedad Intelectual, aprobado por Real Decreto Legislativo 1/1996, de 12 de abril, y la Ley 1/2000, de 7 de enero, de Enjuiciamiento Civil (in Boletín Oficial del Estado 5 novembre 2014, 90404).
} 
welfare, because regulation had a serious side effect in terms of reduction of service level. The "canon AEDE" (the Spanish version of the Google Tax) caused Google to react according to a standard pattern when regulation restricts some behaviors. If there is no chance of vertical integration (Google becoming a publisher and not only a content aggregator), then the other option is complete withdrawal of those behaviors, even when they provide benefits to consumers that exceed the costs imposed on competitors.

Germany also passed new legislation, a solution that was strongly criticized by German intellectual property lawyers in a resolution published by the Max Planck Institute for Intellectual Property and Competition Law ${ }^{13}$. The German Copyright Act (Sec. 87(f)(1)) has been amended as to give the press publisher the exclusive right to make the press product or parts of it available for commercial purposes, except for individual words or smallest text excerpts. The model here is different, because it is based on the choice of the publisher and allows some space for alternative solutions that might avert serious side effects.

Normative reactions to Google News strongly resemble the solution that many years ago was adopted by the U.S. Supreme Court with the hot news doctrine in International News Services $v$.

13 Achtes Gesetz zur Änderung des Urheberrecthsgesetzes del 7 maggio 2013, in Bundesgesetzblatt Jahrgang 2013, Teil I, Nr. 23, 1161.
Associated Press ${ }^{14}$. Also in that case, strong dissenting opinions by Holmes and Brandeis warned of the consequences. Justice Brandeis was clear in saying that «[s]uch taking and gainful use of a product of another which, for reasons of public policy, the law has refused to endow with the attributes of property, does not become unlawful because the product happens to have been taken from a rival and is used in competition with him». After many years, legal systems face the same dilemma.

The Google News case has an Italian prong too. The Italian Antitrust Authority had twice the chance to bring the attention of the Italian Parliament on this issue ${ }^{15}$. In 2011, it remarked the inadequacy of copyright rules to properly address the technological and economic features of internet. In 2013, it insisted on the opportunity for legislative regulation, as a better solution as opposed to "negotiated" solutions. Although there have been legislative proposals, so far the Italian Parliament has not legislated on this topic and likely it will not.

\footnotetext{
14248 U.S. 215 (1918). The case still causes debate and provides stimulus for scholarly and policy debate; see J.L. Harrison, R. Shelton, Deconstructing and Reconstructing Hot-News: Toward a Functional Approach, 34 Cardozo L. Rev. 1649 (2013).

15 See AS787 - Tutela dei contenuti editoriali su internet, January 17, 2011, and AS1050 - Tutela dei contenuti editoriali su internet, May 24, 2013.
} 


\section{ConClusions}

While the press industry in Europe was arming against Google, Mountain View announced the Digital News Initiative, a strategic partnership program for funding sustainable business models in the on line industry. And in France, Google agreed to pay $€ 60$ million euros to a Digital Publishing Innovation Fund with the aim of transitioning newspaper to the online world $^{16}$.

The history of the complex relationship between technological progress, copyright and regulation shows some recurring features that can only be sketched here. Since Sony $v$. Universal Studios, disturbances caused by technology brought about vigorous reactions by copyright holders, that managed to apparently prevail with new laws or precedents by courts against increasingly elegant infringers. It has been the same for Napster, Grokster and all other enterprises that brought serious challenges to copyright laws.

Yet, there is a story that runs in parallel with the official one, and it is the story that brought to light iTunes, YouTube and other digital platforms dealing with digital content. This story is now repeating itself with Google News. The market is shaped by those who are in principle infringers and this process of creation causes periodically legal conflicts and change, either by statutes or case law. The turbulence is only apparently resolved through copyright

16 An initial case (Agence France Press v. Google Inc.) started in 2005 but was settled out of court soon after. laws. As a matter of fact, innovative forms of private ordering are always at work in the shadow of the law to recreate a superior equilibrium ${ }^{17}$. What is left is not destruction of pirates and infringers, but business models that did not exist before. The same is happening with Google News: apparently uncompromising contentious solutions that are made progressively useless by privately created arrangements. The Digital News Initiative is yet another stage of this evolutionary process, where rules do not kill infringers but, to some extent, are only instrumental in identifying those who are strong enough to overcome the obstacle by replacing the pre-existing order with more efficient solutions.

Copyright rules are not neutral ${ }^{18}$. At the same time, it seems like they are not able by themselves to find a convincing equilibrium between innovators and copyright holders. They only set the stage, for a scene that remains dominated by market forces, out of which the strong does not die, but becomes stronger.

If this is what history has handed down to present, it is not necessarily said that there is no way to interact with market forces and prevent solutions that, in the making, can be too restrictive for competition or too dangerous for

\footnotetext{
${ }^{17}$ I tried to better describe this process in M. GRANIERI, La fine è nota: diritto d'autore, evolurionismo giuridico e $i$ meccanismi spontanei di aggiustamento del mercato, in Foro it., 2012, IV, 310.

18 See R. PoDszum, Searching the Future of Newspapers: With a Little Help from Google and IP Law?, 44 IIC 259, 261 (2013).
} 


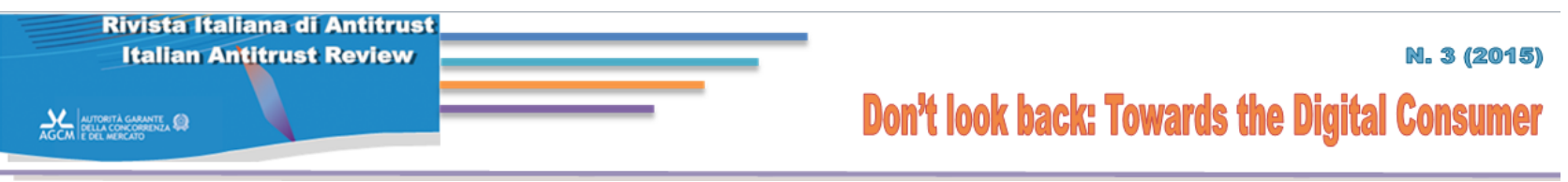

other values, including consumers benefit. An answer can be in self-regulation assisted by authorities that might act as advisors to the parties and take the responsibility of positively showing which directions private ordering should not take. 


\section{REFERENCES}

Edelman, B., Does Google Leverage Market Power Through Tying and Bundling?, 11 Journal of Competition Law \& Economics 1 (2015)

Gal, M.S., Rubinfeld, D.L., The Hidden Costs of Free Goods: Implications for Antitrust Enforcement, www.ssrn.com

Goldman, E., Revisiting Search Engine Bias, 38 William and Mitchell Law Review 96 (2011)

Granieri, M., La fine è nota: diritto d'autore, evoluzionismo giuridico e $i$ meccanismi spontanei di aggiustamento del mercato, in Foro italiano, 2012, IV, 310

Harrison, J.L., Shelton, R., Deconstructing and Reconstructing Hot-News: Toward a Functional Approach, 34 Cardozo L. Rev. 1649 (2013)

Johns, A., The Intellectual Property Wars from Gutenberg to Gates, The University of Chicago Press, 2009

Lucchetta, G., Is the Google Platfrom a Two-Sided Market?, 10 Journal of Competition Law \& Economics 185 (2013)

Macchiati, A., I motori di ricerca su Internet e il mercato delle news. Profili antitrust e regolamentari, in Mercato Concorrenza Regole, 2010, 477

Pardolesi, R., Lincesso, I., "Glourious Basterds»: meraviglie e sortilegi del Google Books Settlement, in Foro it., 2011, V, 11

Podszum, R., Searching the Future of Newspapers: With a Little Help from Google and IP Law?, 44 IIC 259 (2013)

Quinn, D.J., Associated Press v. Meltwater: Are Courts being Fair to News Aggregator?, 15 Minn. J.L. Sci. \& Tech. 1189 (2014)
Reynolds, R.F., Google News and Public Policy's Influence on Fair Use in Online Infringement Controversies, 25 J. Civ. Rts. \& Econ. Dev. 973 (2011)

Visco Comandini, V., Google e i mercati dei servizi di ricerca su Internet, in Mercato Concorrenza Regole, 2013, 547 